Examination may sometimes be bypassed. Once the Canadian Qualifying Examination is passed, one must obtain from a provincial College of Physicians and Surgeons a certificate of appropriate training. This certificate of appropriate training is generally only given to those who have undergone a North American type of rotational internship, covering obstetrics and gynaecology, paediatrics, etc. Some provinces will make the exception of granting this certificate, without evidence of a rotating internship, if the physician has first achieved a Canadian Royal College higher qualification, such as the FRCP(Psych). The Qualifying Examination and the certificate of appropriate training are the two prerequisites to achieve the LMCC.

As Professor Munro indicates, Canada does not accept the British MRC(Psych) as the equivalent of their own FRCP(Psych). In order to take the FRCP(Psych) Canada one must first pass a screening examination. These screening examinations include the Canadian Qualifying or Evaluating examinations and also the FLEX or FMGEMS examinations of the USA. Probably even more crucial than success at a screening examination is the need to have one's training assessed by the Royal College of Physicians and Surgeons in Ottawa. Although British psychiatric training may be passed by the Royal College as being satisfactory, it is not uncommon for the Royal College to decide a further period of residency training is necessary, which can range from six months to two years or longer. This then places the candidate in a position of having to gain entry into a Canadian residency programme, with, of course, having to suffer the financial consequences, in order to complete his eligibility for the FRCP(Psych) examination. This can result in a very traumatic state of affairs for the British trained psychiatrist and we recommend that anyone taking up a permanent position in Canada would be wise to have this formal assessment of their training completed before they leave British shores.

Professor Munro states that "aiding immigration for suitably training psychiatrists ... has become all but impossible". Although we concur that the immigration of British psychiatrists to Canada is becoming progressively more difficult, it is still possible for British psychiatrists to obtain a 'special licence' (limited licence to practise), in certain Canadian provinces such as Saskatchewan and Manitoba, based entirely on their British qualifications. Individuals taking up such appointments, however, still have the steps spelt out above to contend with if they hope to achieve a general licence to practise and wish eventually to obtain their Canadian general medical and psychiatric qualifications.

Finally, with the intricacies outlined above, it would be interesting to hear the position of the British Royal College of Psychiatrists in respect of physicians who hold Canadian qualifications and wish to practise in the United Kingdom.

C. Green

S. MANOHAR

Regional Psychiatric Centre (Prairies)

Saskatoon, Saskatchewan, Canada

\section{Abuse and neglect of the elderly mentally infirm}

\section{DeAR SirS}

I and colleagues from other disciplines have recently been involved in cases where there has been physical abuse and/ or neglect of an elderly mentally infirm person and we are trying to formulate a policy or procedure to deal with these cases, which unfortunately seem to be on the increase.

I would be very grateful for any help or advice from members who have tried to deal with similar problems in their own practice, especially if they know of or have devised a workable procedure in their own districts.

Whitchurch Hospital

Delyth AlLDRICK

Cardiff

\section{Children allegedly killed or injured by nannies}

\section{DEAR SIRS}

I have seen two cases where nannies have allegedly killed or injured children in their care, and a colleague has seen a similar case. I should like to hear from other colleagues who have seen cases of this kind.

O. V. BRISCOE

The Maudsley Hospital

Denmark Hill, London SE5 8AZ

\section{Gilles de la Tourette's Syndrome}

\section{DeAR Sirs}

I write in the hope that you can assist me in tracing the address of a support society in Britain for sufferers from Gilles de la Tourette's Syndrome and their relatives.

Thank you for your assistance.

R. V. SCHNEIDER

\section{Lindsay Miller Clinic}

Launceston General Hospital

Launceston, Tasmania 7250

\section{Layout of 'Bulletin'}

\section{DEAR SIRS}

I do feel that much could be done to increase the attractiveness and readability of the Bulletin. The present layout and type-face is most off-putting and I feel hardly inspires the reader to keep up to date with College news and views.

We live in an age of computer desk top publishing and by comparison the Bulletin looks as though it were laboriously assembled by one of Caxton's assistants.

Drug Dependence Clinical Research

ANDREW R. JOHNS and Treatment Unit

The Maudsley Hospital, London SES

Editorial Note: This matter is under active consideration. 